\title{
MONGOLIAN ECONOMY AT THE THRESHOLD OF GLOBALIZATION ERA
}

\section{By Ts.Baatar (Mongolia)}

It has been passed a decade since Mongolia chose the development path of democracy and market economy and now we are already in second decade of our endeavors. During the past period Mongolia has achieved quite a bit success for its efforts towards transformation of its economy into classic liberal forms of property ownership and its various forms and put the market principles on their own path of development.

However, the process of transformation into free market principles overcoming the huge authoritarian rules of the economy was not easy as it was originally expected.

Although Mongolia was ahead of other transitional countries such as its neighbor Russia as well as the newly independent central Asian states such as Kazakhstan, Kyrgyzstan, Uzbekistan, Tajikistan and Turkmenistan for its privatization and other achievements there were considerable setbacks in agricultural development, specially in animal husbandry and agriculture fields due to hasty actions in privatization.

There were setbacks in other areas of economy as well. It can be pointed out that in this globalization era one of distinctive features of the present economic policy of Mongolia is its tremendous efforts towards more and more open and free economy correcting setbacks and reinforcing achievements.

Let me briefly introduce economic data of Mongolia as of 2002. Comparing with the data of 2001 the total output of industrial production in 2002 has been reduced 0.3 percent. It was estimated that the expected economic growth rate in 2002 would be around 3 percent. ${ }^{1}$

The fall in industrial output was mainly due to the fall of production in mining sectors by 12,6 percent, in electricity (heating) and water supply fields by 4 percent respectively. However, the output of processing industries was increased by 18,9 percent. Freight transport (transported goods) has increased and the number of passengers taking rail roads has decreased while the number of passengers taken airplanes has not changed. In 2002 the total number of livestock has decreased by 9 percent or 2,4 million heads. This number indicates that the year 2002 was considerably unfavorable year for the animal hus-

\footnotetext{
${ }^{1}$ Social and Economic Development Objectives for 2003. Development Strategy for 2004-2006. Government of Mongolia
} 
bandry of Mongolia. In 2002 the most worsely affected animals by natural calamity were sheep and camels and the less affected animals were goats.

The annual inflation rate in 2001 was 8,3 percent and this figure was decreased in 2002 reaching 3 percent. ${ }^{2}$ The fall of inflation rate was basically due to price decrease of food products. However, the overall price was kept upward direction due to the increase of prices in housing, electricity and heating.

Compared with US dollar and Chinese yuan Mongolian tugrig (national currency) has been kept weakening and subsequently the weakening process accelerated in the second half of 2002. The increase of the value of Mongolian tugrig vis a vis Russian ruble and Japanese yen slowed down. In 2001 the value of tugrig vis- a- vis Korean won and Euro increased and in 2002 it changed in the opposite direction, namely the value of tugrig decreased.

If in 2001 money supply increased by 28 percent then in 2002 by 42 percent. Increase of fixed-term savings and foreign exchange holdings were the main causes of the above-mentioned increases in money supply. Foreign real assets in banking system (mostly in central bank) increased by 40 percent and local loans increased by 55 percent. The level of nominal interest rate of loan decreased slightly and the level of real interest rate compared with the level of 2001 increased.

The increased level of budget expenditures was the main cause of budgetary deficit in 2001 equaled to 3,9 percent of gross national products and in 2002 $-5,4$ percent. This shows the increased role of state financing in 2002. In 2002 the budget income constituted 36,3 percent of GDP and current expenditure 31,7 percent and the total expenditure- 41,7 percent respectively. The income derived from the privatization of the Trade and Development Bank has contributed greatly for the payment of budget deficit.

Export has decreased by 3,9 percent and import has increased by 3,3 percent and the trade deficit has reached $\$ 158$ million constituting 14 percent of GDP in 2002. The same number was 11 percent in 2001. Among Mongolia's main export items the export of mineral resources and cashmere decreased considerably and export of gold increased by 58 percent. Import has been increased due to the increased amounts of importation of textiles, foodstuffs, machines and equipment.

According to the Law on land ownership adopted by the State Great Hural in 2002 citizens have right to own land. 500 delegations from 44 countries from around the world and 17 international organizations participated at the ninth

${ }^{2}$ Change in annual average of consumer price index 
meeting of donor communities held in Mongolia last year. They promised Mongolia to accord assistance in total amount of $\$ 330$ million.

Since 1990 till now 2400 foreign companies from 70 countries invested over $\$ 800$ million in Mongolia and 68 percent of them are joint ventures and 32 percent are 100 percent foreign owned companies.

Among foreign companies 26 percent of them invested in mining sector, 12 percent in light industrial sector, 7 percent in sectors of reprocessing of agriculture raw materials, 7 percent in construction field, 5 percent in public service sectors, 4 percent in bank and financial sectors and the remaining 39 percent in other sectors of Mongolia's economy.

Mongolia's banking system is stabilized and increasing competition thanks to assistance, project loans, studies carried out in financial sector and other measures taken by international financial organizations such as World Bank and Asian Development Bank during 1996-1999.

Privatization of large commercial banks is still under way. In 200276 percent of state-owned shares of the Mongolia's largest commercial bank- the Trade and Development Bank-was sold to "Banka Commercialle Lugano" of Switzerland and "Gerald Metals" consortium of the USA for \$12 million and \$23 million respectively.

ING Group of Netherlands undertook management of the privatized Trade and Development Bank. We believe that all these measures would help us to introduce new services into Mongolia's banking sector.

Mongolia's second largest and 100 percent state owned commercial bank - the Agriculture Bank- has been privatized at the end of January in 2003. It was sold to HS Securities of Japan for $\$ 6.8$ million. Now the issue of privatization of the remaining Savings Bank is under consideration.

After all the main purpose of privatization of banking sector is to reduce the state interference in and influence on bank activities.

At present 16 commercial banks, about 70 non-banking financial institutions, over 140 savings and credit cooperatives and over 850 pawnshops are operating in Mongolia.

Starting from last year several banks have introduced new services such as Internet banking, Master and Visa Card services. Today these kinds of new services are growing steadily and number of customers is constantly increasing.

All these measures are making positive influence on stabilization of macroeconomic environment. On the other hand, it is an indication of increasing number of borrowers that own their business and properties.

Normalization of commercial bank activities, increased number of non- 
banking financial institutions and savings and loan partnerships have facilitated increased cash flow creating a favorable conditions for falling interest rates. Foreign investors began to invest in Mongolia's financial market. For Instance, Millennium Security's Management Company of Russia that registered in Virginia Islands of Great Britain is conducting non-banking financial business in Mongolia. This Company lends mostly for large investment projects. Its annual interest rate is 12-14 percent, which is the lowest one in Mongolia at this point.

However the interest rate is still high in Mongolia. 84,4 percent of the total bad loan belongs to private sector and the remaining 4,6 percent to the state sector.

During the last few years the savings rate is taking an upward trend. This trend is taking place due to the macro economic stabilization, increased flow of cash into banks, increased flow of foreign private savings, increased interest rate competition among banks as well as increased competition among nonbanking financial institutions.

Transmission of private savings of Mongolian citizens working in South Korea, USA, Germany, Great Britain, Japan and other countries is steadily increasing. The total amount of incoming private transmission of citizens working abroad is 2-3 times more than the amount of foreign direct investment in Mongolia. All these factors are influencing not only on local savings rate but also on stabilization of exchange rate.

Small "Mongolian towns", like the China towns around the world, are emerging in South Korea as well as in the United States of America. This can be judged as one of positive signs influenced by democratization and globalization processes in Mongolia as well as in the world.

In this way Mongolia has made a progress towards creating a more open and transparent banking and financial sectors and the most favorable legal environment for financial investment. Although much has been done in Mongolia's banking sector, almost nothing has been done in regard to the stock market reform. It is still missing a concerted policy for regulation of free flow of foreign exchange in this globalization era. In other words, Mongolia has to learn lessons from the Asian financial crisis.

The future of nomadic way of animal husbandry practiced in Mongolia is still remaining unclear. Although intensive discussions about the need to introduce an intensive way of animal husbandry are taking place at government as well as grass roots levels, the proper way of solution to this problem remains to be found. Ever increasing environmental degradation and ecological issues are giving an alarming signal to Mongolia's nomadic way of animal husbandry. Any 
way it is so clear that the existing way of nomadic life is no longer appropriate now.

In short this is the present state of Mongolia's economy. It is interesting to compare this study with the conclusion of studies made by foreign researchers on comparison of Mongolia with the other countries of the world. This type of study is needed because we-Mongols-are accustomed too much to our own environment as well as to our own assessment.

In my view, J \& Austin Associates/ JAA/ Company of the United States of America has made a very competitive study in the contemporary history of Mongolia. JAA is a big company, headquarter of which is located in Arlington City, Virginia and its main activities are making research in the field of economic reform and private sector development. This company carried out over 400 projects in 80 countries of the world.

Researchers of the company made comparative studies on Mongolia's economic situation, her export, investment, financial sector, policy environment, science and technology development, infrastructure and human resource. The above-mentioned eight fields are considered in the world as causes and consequences of competitiveness.

Economic situation: Per capita income is very low. The total output of GDP is only $\$ 1$ billion. Mongolia is rated as the 131-st country among those countries covered by their comparative studies. GDP in Mongolia is not calculated accurately due to illegal border trade and underground economic activities. Even though per capita income in Mongolia is constituted \$390 placing her as the 103-rd country among 136 countries involved in the comparative studies. The growth rate of Mongolia's GDP is constituted 3,3 percent. It means Mongolia is $87^{\text {th }}$ country among the 136 countries. For the economic growth rate Mongolia occupies one of the lowest place among the above mentioned countries.

Export: Mongolia's total export constituted $\$ 430$ million placing itself as the $133^{\text {rd }}$ country among 186 countries of the world. Export amount per person is $\$ 143$ becoming $130^{\text {th }}$ country among 176 countries. Export production and services constitute 55 percent of GDP occupying $28^{\text {th }}$ place among 152 countries.

Investment: For the total amount of her local investment Mongolia is $59^{\text {th }}$ country among 136 countries. For the amount of share of foreign investment in GDP and per capita foreign investment Mongolia is rated as the $102^{\text {nd country }}$ among 136 countries.

Financial sector: According to the study for the level of this sector's development Mongolia is rated as one of countries with a very weak banking 
sectors. Mongolia is rated as the 113th country among 133 countries for the amount of share of local loans of banking sector in GDP.By the share of total money supply in GDP Mongolia is rated as the $94^{\text {th }}$ country among 131 countries. For the level of financial risk Mongolia is rated as the $73^{\text {rd }}$ country among 186 countries.

Policy environment: Neither of the world's largest organizations such as "Heritage" as well as "Frazer Institute" that usually carry out a research works in this field did mention Mongolia. Anyhow judging from the latest data on Mongolia's budget deficit and inflation rate they included Mongolia into the group of lowest developed countries. However, they are more or less positive about the open door policy of Mongolia. Mongolia is rated among the most open countries for her share of trade in GDP.

Science and technology: According to the World Bank study carried out in 1997 Mongolia has around 13 thousand computers. However, some researchers argue this number has doubled during the past few years. In 1997 Mongolia was rated as the $72^{\text {nd }}$ country among the 103 countries for the number of computers. As for the Internet connections Mongolia was the $106^{\text {th }}$ country among 146 countries.

According to the above mentioned study new technology export is constituted only 2 percent of the total export of finished products. This means Mongolia is the $85^{\text {th }}$ country among the 94 countries for this indicator. However, Mongolia is rated above the world's average level for the numbers of scholars and engineers. In other words, Mongolia was rated $37^{\text {th }}$ country among the 75 countries.

Infrastructure: An infrastructure development level is usually determined by the level of per capita production of electricity, and capacity of transportation as well as communication. Mongolia is rated $94^{\text {th }}$ country among 149 countries for the number of per capita telephones. In other words, there are 37 telephones for each 1000 persons. However, this number is very changeable due to the newly introducing cellular phones. Mongolia's telephone charge is rated one of the most expensive ones in the world placing her $95^{\text {th }}$ country among 108 countries.

Human resource and manpower: Mongolia has been rated $119^{\text {th }}$ country among the 174 countries for the human development index of the UNDP. The average life expectancy in Mongolia is 66 years which means Mongolia is in $106^{\text {th }}$ place for this indicator among 166 countries. Mongolia is also rated as the $99^{\text {th }}$ country among the 148 countries for infant mortality. It was not so long ago that Mongolia had received UNESCO award for total elimination of illiteracy among her population. However, it is quite surprising that according to 
one recent study Mongolia was rated as the $75^{\text {th }}$ country among the 143 nations for her literacy rate.

Mongolia is placed on $5^{\text {th }}$ place in the world for the dependence on foreign loans and assistance. In this category of countries usually are included those poor countries that have been affected by economic disaster, countries that lack capability to be developed in the near future and countries simply do not have ability to manage themselves.

According to the study 20,6-28,2 percent of GDP's of Mozambique, Nicaragua, Malawi, Laos and Mongolia are official development assistance. The rich countries call them "official beggars" and their people in most cases are not supportive to providing aid to them.

Mr. Kit Griffin, chairperson of the UNDP research group and distinguished professor of University of California made the following conclusions on this matter.

Although the idea of donors to help the poor nations seems good the consequences of loans and assistance are disastrous. Foreign loans and assistance are creating obstacles to the local reform process and diminishing the state ability to manage its economy and overcome the transitional difficulties. In 1995 per capita income was 4,7 percent and it was calculated that this figure was gradually diminished until zero point in 2001./ It is quite doubtful that the figure was about 3 percent in 2002/

Mongolia is receiving a lot of loans from abroad not in order to develop but in order to meet her current consumption. Terry McKinley (USA) wrote that this is a dangerous strategy. He made a research in Mongolia's economy and warned the government on the following issues:

Mongolia has received loans amounting to almost $\$ 1$ billion. In some time later this country has to pay back those loans. If the economic growth rate and export production remain unchanged then it would be very difficult for her to pay back loans already taken and then the fate of the country will be in donors' hands. In past 10 years the largest lenders to Mongolia are become the Asian Development Bank (32 percent of the total loan), Japan (21 percent of the total loan), Germany, Russia, China and Norway (all together 12 percent of the total loan received by Mongolia and about 20 percent of the total commercial loans).

In other words, the Western world spent about \$2 billion in Mongolia during the past 10 years. Of course this amount is not so big if we compare with \$30 trillion world GNP, or with $\$ 350$ billion annual defense spending of the USA, or with $\$ 10$ billion of the Japanese annual aid budget to the developing world. However, if we compare the total loan received by Mongolia with her 
population the amount of loan seems astronomical. In other words, this sounds like during the above-mentioned period Indonesia received \$200 billion. In reality to our big surprise Indonesia received only less than $\$ 15$ billion loan or $\$ 6$ per person during 10 years.

Mr. Terry McKinley once again warned that Mongolia's economic policy should not be based on the assumption that the loans will be written off in the future even though the donor communities would write off the half of their loans.

There was published another research work on Mongolia by Americans last year. The conclusion of the research work was distributed limited number of copies in the name of "Soros foundation". It is a serious research work that required many years' hard work and efforts as well as resources. This research work has showed the present Mongolian society, politics, economy, human resource factor, foreign relations, sociology, and the state of social pchycology in very accurate ways. Many specialists in various fields were involved in this research.

Here I would like to pinpoint again that quality of research usually depends on neutrality of researchers. In this sense this research is realistic and at the same time is more alarming. Of course, the meaning of alarming is only relevant for Mongolians not for the others. The reason of mentioning about the alarming is that the research made a rather gloomy picture about the present and future trends.

The gloomy pictures of Mongolia were described in the following phrases: in geographical as well as in geopolitical sense is not attractive except Russia and China, no mineral resources and market attractive to foreign investors, corrupted government, inappropriate state structure and system, no any appropriate political parties, verge of environmental and climate extinction, no potential resources of mining/ except Oyu Tolgoi copper and gold deposit- author/, very limited market, intensive brain drain process, no any policy regulation in regard to migration taking place within the country, inappropriate and wasteful organization of local administration, no legal environment, social gaps among rich and poor, old and young generations, educated and uneducated ones, rural and urban are broadening from day to day, most population has a mentality against the fact of globalization process, no business mentality or lack of it.

It is high time for us- Mongolians- to think about the above-mentioned definitions regarding our nation and people. In one word, we are on the verge of devastation.

We-Mongolians- need such a good quality that the Japanese as well as Koreans have when their nations are on the verge of disaster dedicate them- 
selves and their belongings to save their nations. Now we are standing just in front of such a test.

Although Mongolia's present and future look like rather gloomy it is also appropriate to point out here the positive trends that are taking place in this country. "Standard \& Poor"- one of the largest organizations that makes assessment of country's development trends and economic situation made an assessment of Mongolia's development trends in March 2002. According to this organization's assessment Mongolia was rated as " $\mathrm{C}$ " in 1999 and as "B+" in March 2002. This assessment shows that there are some progress in Mongolia according to international standards of assessment. This means that Mongolia has some hope to develop fast if the advanced nations continue to assist pushing her towards the arena of globalization. 